\title{
Population Distribution of Amorphophallus at Several Altitudes in Mount Poteng, Raya Pasi Nature Reserve, West Kalimantan
}

\author{
Reine Suci Wulandari, Selvia Ivo*, Herlina Darwati \\ Faculty of Forestry, Tanjungpura University. Jalan Daya Nasional, Pontianak, 78124, Kalimantan Barat, Indonesia \\ ${ }^{*}$ Corresponding author. E-mail address: selviaivo899@gmail.com
}

\section{ARTICLE HISTORY:}

Received: 18 October 2021

Peer review completed: 7 December 2021 Received in revised form: 9 January 2022 Accepted: 24 January 2022

\section{KEYWORDS:}

Altitude

Amorphophallus

Mount Poteng

Raya Pasi Nature Reserve

(C) 2022 The Author(s). Published by Department of Forestry, Faculty of Agriculture, University of Lampung in collaboration with Indonesia Network for Agroforestry Education (INAFE).

This is an open access article under the CC BY-NC license:

https://creativecommons.org/licenses/by$\mathrm{nc} / 4.0 /$.

\begin{abstract}
Amorphophallus is a protected and endangered plant. Some Amorphophallus species can only grow in certain environmental conditions. Differences in environmental conditions could cause differences in morphology and distribution of Amorphophallus. This study aimed to obtain the morphological characteristics of Amorphophallus and study the distribution of its population at several altitudes in Mount Poteng, Raya Pasi Nature Reserve, West Kalimantan. The study used an exploratory survey following the river's flow at the Raya Pasi Nature Reserve, especially in Mount Poteng. The results found three species of Amorphophallus: Amorphophallus borneensis (109 individuals), Amorphophallus gigas (9 individuals), and Amorphophallus hewittii (27 individuals), showing clustered distribution patterns with a Morista index of $>1$. The similarity index of six comparisons for each altitude showed five altitudes with similar categories and one altitude with a very different category. The results revealed that the Amorphophallus distribution positively correlated with air temperature and soil temperature but negatively correlated with air humidity. However, all correlations were weak. The morphological differences of the three Amorphophallus species were in the forms of the stem pattern, stem height, and fruit shape. The distribution of Amorphophallus can be found at an altitude of $200->500$ masl, which is not far from the river flow.
\end{abstract}

\section{Introduction}

Nature reserve has the uniqueness of plants, plant diversity, natural phenomena, and ecosystems that need to be protected and preserved so that their existence and development can occur naturally (KLHK 2020). One of the nature reserves in West Kalimantan is the Raya Pasi Nature Reserve. The nature reserve has a total area of 3,700 ha, located in Singkawang City and Bengkayang Regency, West Kalimantan Province. The Raya Pasi Nature Reserve management is under the Conservation Unit III Singkawang, Natural Resources Conservation Agency (BKSDA) of West Kalimantan. Raya Pasi Nature Reserve consists of 10 mountains, including Mount Poteng, with an altitude of \pm 725 masl. Mount Poteng has many unique and protected flora and fauna, such as bunga bangkai (Amorphophallus). Based on Government Regulation (PP) of the Republic of Indonesia Number P.106 of 2018, Amorphophallus is listed as a protected plant. Amorphophallus, known as bunga bangkai, is also one of the rare flora in Indonesia, which is currently threatened and is under conservation status. Amorphophallus was categorized as vulnerable (V) by the 1997 
edition of the IUCN Red List of Threatened Species, but in 2002, it was removed from the IUCN Red List of Threatened Species (Arianto et al. 2018; Yuzammi et al. 2014). To date, the research on the presence and population of Amorphophallus in Mount Poteng, Raya Pasi Nature Reserve, West Kalimantan is still lacking.

The morphological characteristics of Amorphophallus found in Mount Poteng can be distinguished from the stem pattern, stem height, and fruit. The morphology of the Amorphophallus can change due to environmental factors of its habitat and growth place, so it is necessary to know its morphological characteristics in Mount Poteng. Amorphophallus can be distinguished by the stem color, stem pattern, surface color of the tuber, and leaves color (Aisah et al. 2017). Amorphophallus requires specific environmental conditions. Hence, the species is rarely found because it only grows in locations with a certain altitude. Altitude affects the population of Amorphophallus on Mount Poteng, so it is necessary to know the distribution of Amorphophallus at each altitude. Altitude is one of the environmental factors related to where plants grow, the difference in altitude will affect the growth of a plant related to temperature, humidity, and light intensity. Research by Saragih et al. (2015) said that the A. hewittii species could be found at an altitude of 101-200 masl. Therefore, Amorphophallus can be found on Mount Poteng at an altitude of 200-500 masl and decreases above it to the peak (725 masl). In contrast, the research results of Heriyansyah et al. (2017) showed that the altitude range for Amorphophallus is 50-846 masl.

The population of Amorphophallus has decreased from year to year. For example, Yuzammi et al. (2015) found that in Kapahiang, Bengkulu Regency, the Amorphophallus population was less than 50 individuals, with a population distribution growing in groups. If this situation is ignored without any attention from relevant parties, it could cause the extinction of Amorphophallus in nature. However, there is still no information on studies that reported the distribution of Amorphophallus at several altitudes. In particular, the distribution of Amorphophallus at several altitudes in Mount Poteng. It is hoped that knowing the distribution pattern of Amorphophallus can provide input for further conservation management so that the extinction does not occur. Therefore, this study aimed to obtain the morphological characteristics of Amorphophallus and study the distribution of its population at several altitudes in Mount Poteng, Raya Pasi Nature Reserve, West Kalimantan.

\section{Materials and Methods}

\subsection{Study Area}

The study was carried out from July to August 2020 in Mount Poteng at an altitude of 200 to $>500$ masl in the Raya Pasi Nature Reserve area, West Kalimantan (Fig. 1). The study used an exploratory survey following the river's flow at the Raya Pasi Nature Reserve, especially in Mount Poteng. Field observations of Amorphophallus were conducted based on an altitude of $200-<300$ masl, $300-<400$ masl, $400-<500$ masl, and $>500$ masl, starting from the boundaries of the Raya Pasi Nature Reserve in Mount Poteng and following the Poteng River stream.

\subsection{Data Collection}

Observations and data collection were carried out on the species and number of Amorphophallus found in each altitude group. Then, environmental data were collected at every 
point where Amorphophallus was found. The environmental data were measured, including light intensity, air temperature, air humidity, soil solum thickness, soil temperature, and soil $\mathrm{pH}$. Air temperature and humidity were measured using a thermohygrometer. The light intensity was measured using a lux meter, soil temperature was measured using a soil thermometer, soil $\mathrm{pH}$ was measured using a pH meter, and soil solum thickness was measured using a scaling pole.

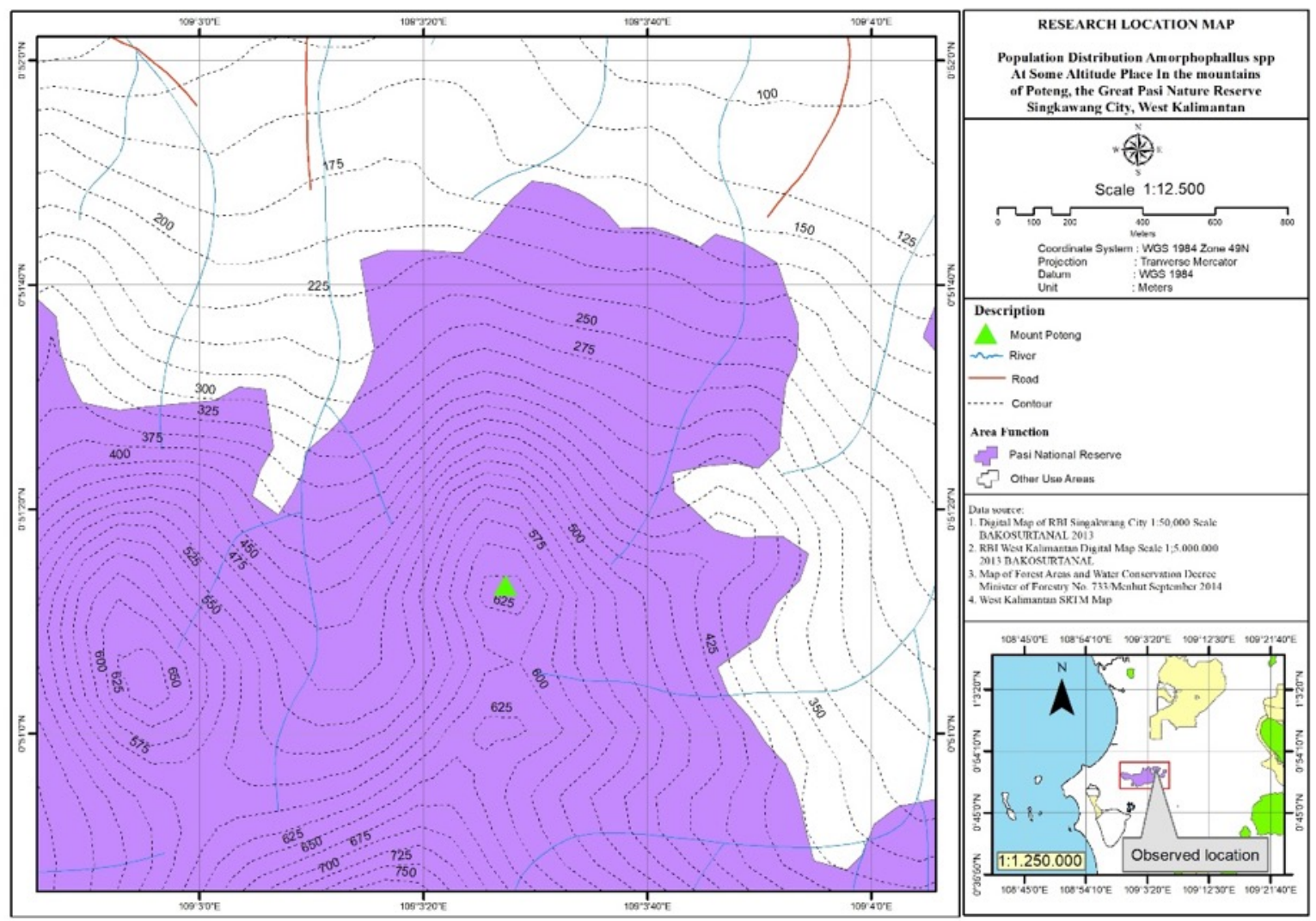

Fig. 1. Research location in Mount Poteng, Raya Pasi Nature Reserve, West Kalimantan.

Data collection of Amorphophallus was started from the boundaries of the Raya Pasi Nature Reserve with an altitude of 200 masl, from the left of the Poteng River by drawing the river's width with a radius of $20 \mathrm{~m}$ (Fig. 2). After reaching $20 \mathrm{~m}$, the direction of the path was then pulled up until it was reached the altitude of 533 masl. The direction of the $20 \mathrm{~m}$ path was divided into two $10 \mathrm{~m}$ each to facilitate the accuracy of data collection. After finishing on the left of the Poteng River, it was continued on the right side of the Poteng River with the same conditions.

\subsection{Data Analysis}

\subsubsection{Morista index}

The Morista index formula was used to determine the distribution pattern of the Amorphophallus species and calculated using the following equation (Khairil et al. 2015).

$$
I_{\delta}=N \frac{\sum x^{2}-\sum x}{\left(\sum x\right)^{2}-\sum x}
$$

where $N$ is the total number of samples and $x$ is the number of individuals. If $I_{\delta}$ of $1=$ random distribution, $I_{\delta}<1=$ uniform distribution, and $I_{\delta}>1=$ group distribution. 
In addition, to determine the distribution pattern of Amorphophallus at each altitude of Mount Poteng, the data were presented spatially in the form of a distribution map per height. The distribution map was developed by entering the coordinates from the Global Positioning System (GPS) tracker into the base map (Map of Mount Poteng, Raya Pasi Nature Reserve).

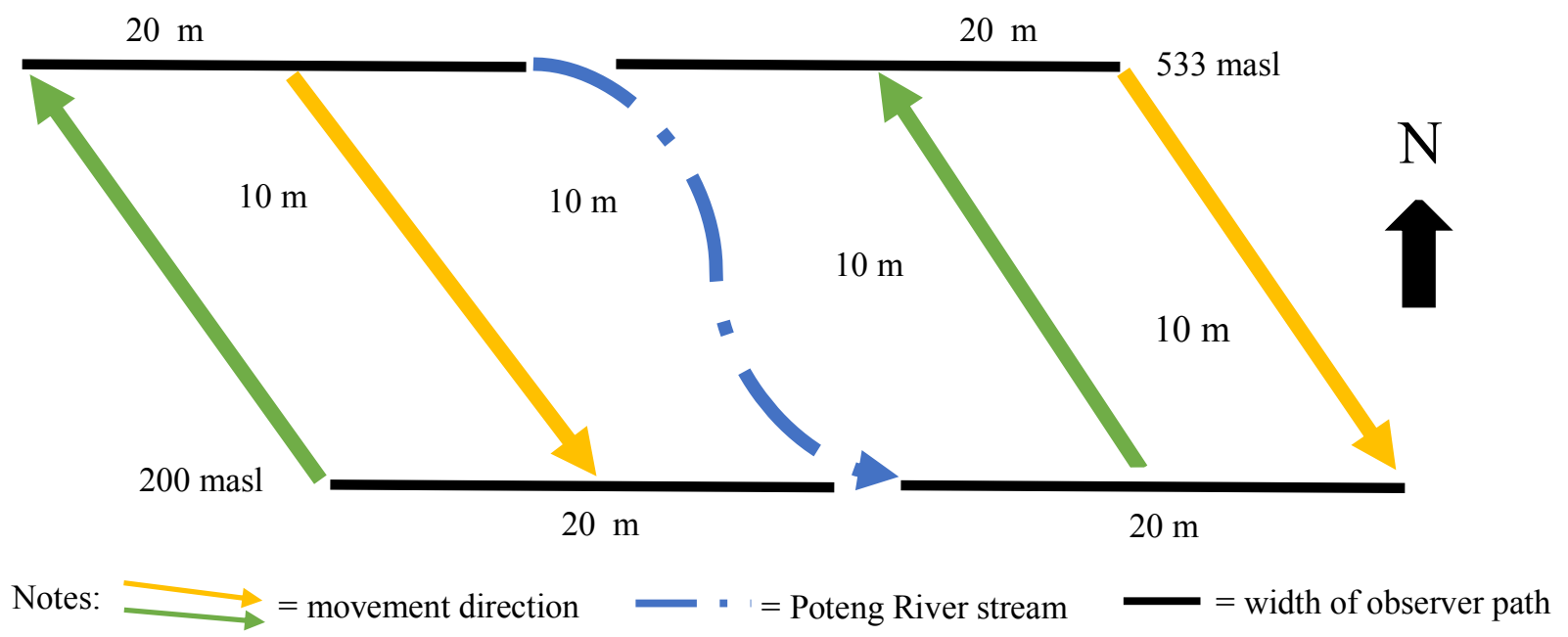

Fig. 2. Research path scheme.

\subsubsection{Similarity index}

The similarity index $(S I)$ was used to compare among altitudes using the Sorensen formula (Tarida et al. 2018).

$$
S I=\frac{2 C}{A+B} \times 100 \%
$$

where $C$ is the same number of species found in both communities, $A$ is the number of species in community $A$, and $B$ is the number of species in community $B$.

\subsubsection{Relationship of environmental factors with Amorphophallus}

The relationship between environmental factors and the distribution of Amorphophallus was determined by comparing the distribution of Amorphophallus with the results of measurements of environmental factors such as light intensity, air temperature, air humidity, soil $\mathrm{pH}$, soil temperature, and soil solum from several altitudes. The data were then analyzed to find the correlation value using the IBM SPSS Statistics application.

\section{Results and Discussion}

\subsection{Amorphophallus Species in Mount Poteng}

The results found three Amorphophallus species at several altitudes of Mount Poteng, Raya Pasi Nature Reserve, namely Amorphophallus borneensis, Amorphophallus gigas, and Amorphophallus hewittii. The morphological differences of the three Amorphophallus were in the forms of the stem pattern, stem height, and fruit shape.

A. borneensis has a height of up to $180 \mathrm{~cm}$. The young saplings have leaf buds that are still rolling, which will later bloom and be divided into three branches with a maximum height of 90 $\mathrm{cm}$ (Fig. 3a). The color of the leaves is light green to dark green with an oval leaf shape, pinnate 
leaf blade, pointed leaf tip, and compound leaves (Fig. 3b). The stem grows upright above the tuber in the ground, so it is called a single stem or pseudo-stem. Adult stems are divided into three branches and then subdivided into 2-3 sub-branches, light green to dark green in color, smooth surface and has a mottled pattern of white, round, pale green to dark which covers the surface of the trunk with various shapes (Fig. 3c). The fruit is a compound fruit, green when young and reddish yellow when old, oval-shaped fruit that varies in size and has a black butt at the end of the fruit (Fig. 3d).
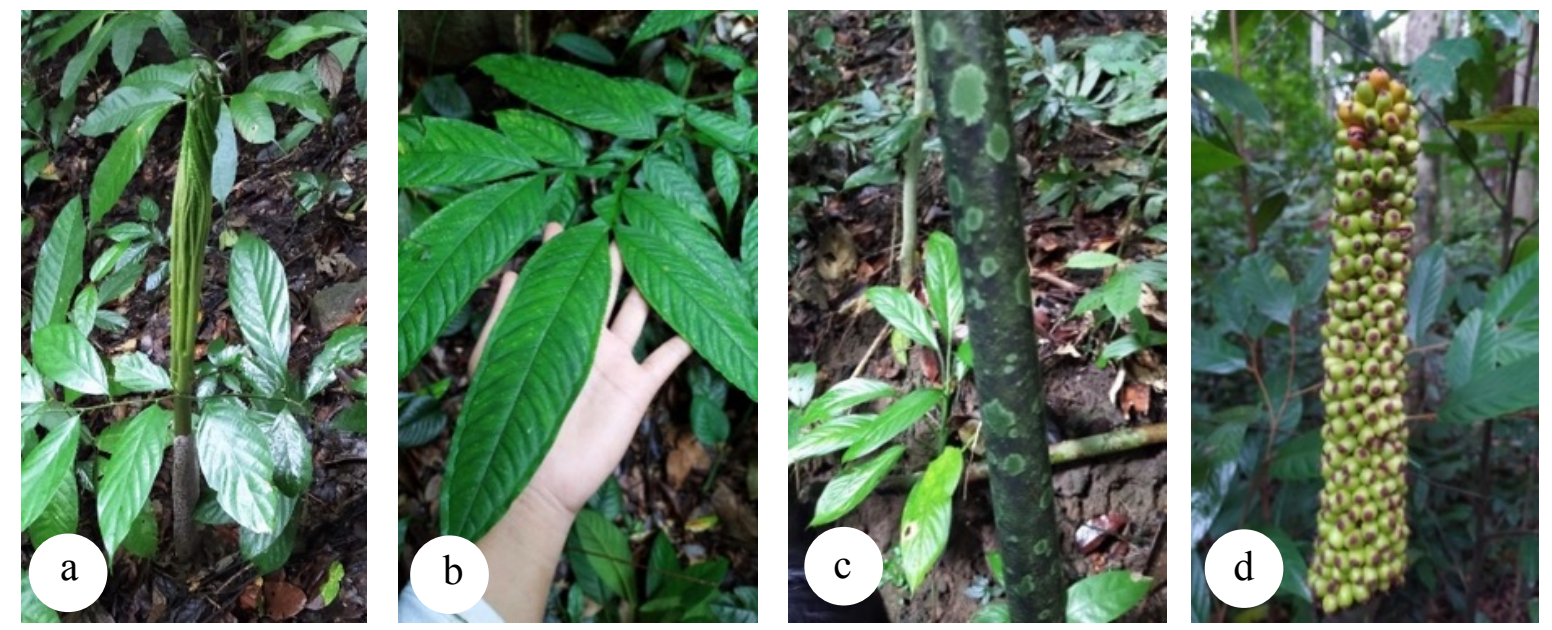

Fig. 3. Morphology of A. borneensis: (a) young leaves and tillers, (b) leaves, (c) stem pattern, and (d) fruits.

The results showed that $A$. borneensis in Mount Poteng had similar morphology with $A$. paeoniifolius in the Palu Valley in the forms of the stems, leaves, and fruit. A. paeoniifolius could reach a height of 1.5-2 m, pseudo-stem is round in shape, light green to dark green, and has white spots. The surface is speckled, and the stem is divided into three branches. The leaves of $A$. paeoniifolius are light to dark green, and the tips are tapered. The fruit is green to orange when unripe, which turns to red when ripe, and inside of the fruit, there are 1-2 seeds with oval shape (Jintan et al. 2015). Hidayat (2019) stated that A. paeoniifolius is a strong herbal plant with 1.0$1.5 \mathrm{~m}$ high.

A. gigas has a height of up to $250 \mathrm{~cm}$ and a smooth stem surface patterned with small greenish-white stripes that vary on each stem surface (Fig. 4a). A. gigas has compound leaves, light green to dark green color, wide with oval leaves, pinnate leaf blades, and has pointed leaf tips (Fig. 4b). The large stem is dark green, and the stem is a pseudo-stem that grows on tubers in the ground. The stem has three branches and is further divided into 2-3 sub-branches (Fig. 4c). The morphology of $A$. gigas in Mount Poteng has similarities with A. titanum in terms of the morphology of the stem, which has a length of up to $5 \mathrm{~m}$ with a smooth stem surface, green or dark green color with oval to rounded spots varying in size and shape, pale green, and the leaves are ellipse, green, and pointed at the tip (Yuzammi et al. 2015).

A. hewiitti found at Mount Poteng has a height of up to $180 \mathrm{~cm}$, the color of the stem is green, and the surface of the stem is slightly rough with small greenish-white stripes with various shapes covering the surface of the stem (Fig. 5a). The leaf of $A$. hewiitti is compound leaves, oval shape, lined blades, pointed tips, and has light green to dark green color (Fig. 5b). The adult stem is divided into three branches divided into 2-3 sub-branches, while the saplings have three-leaf 
branches and a maximum height of $100 \mathrm{~cm}$ (Fig. 5c). The fruit is round in shape, and it is green when young and yellow when ripe, with a black tip at the end of the fruit (Fig. 5d).
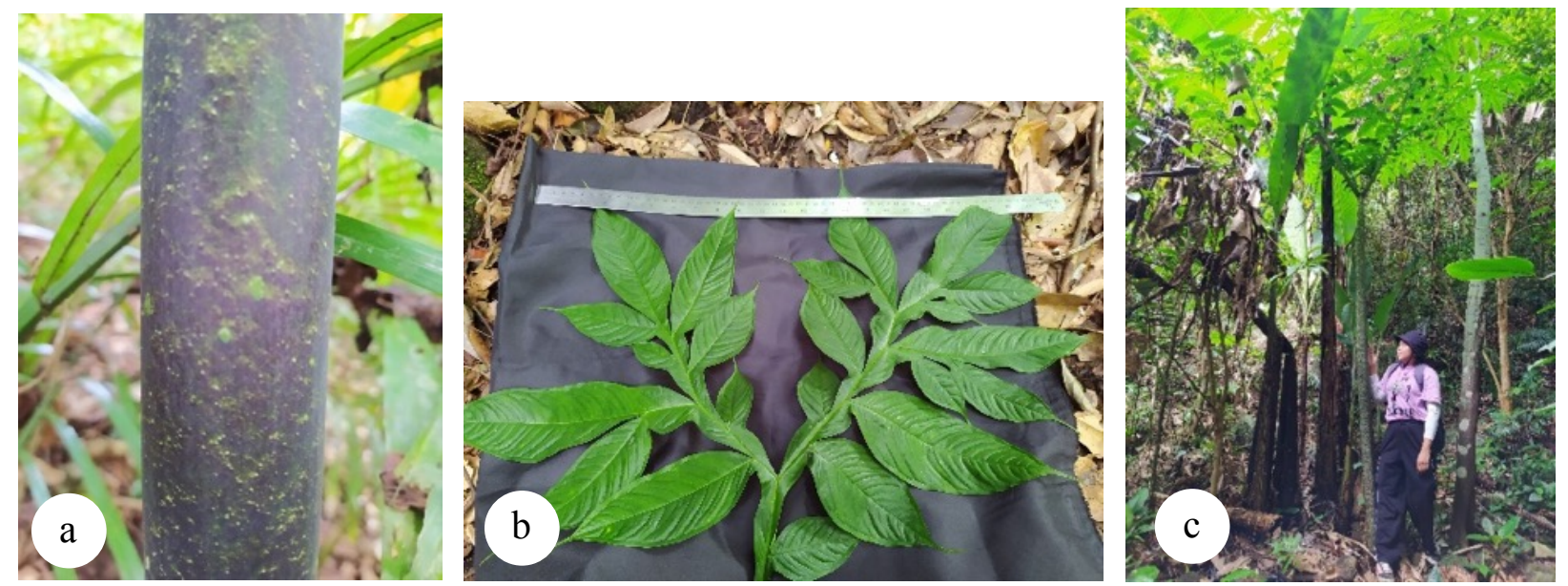

Fig. 4. Morphology of A. gigas: (a) stem pattern, (b) leaves, and (c) mature plant.
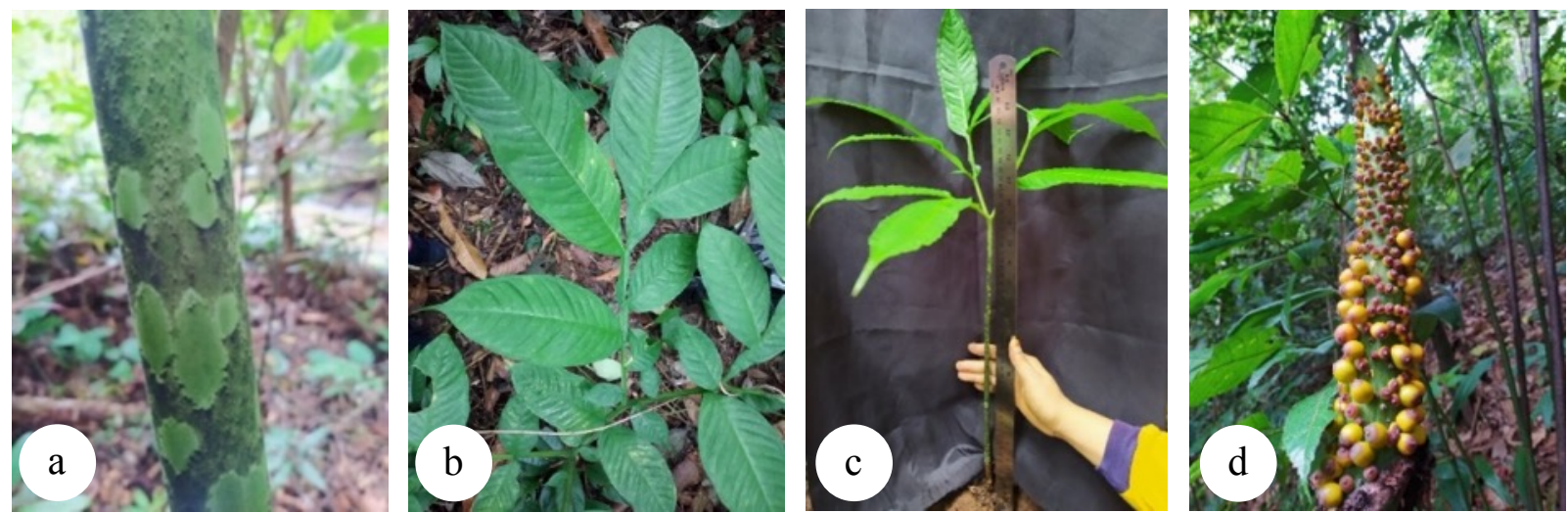

Fig. 5. Morphology A. Hewittii: (a) stem pattern, (b) leaves, (c) tillers, and (d) fruits.

Saragih et al. (2015) also found $A$. hewittii species at an altitude of 101 - 200 masl, showing the stem height of up to $180 \mathrm{~cm}$, rough stems with green and purple color, and small white spots covering the entire stem surface. The cubs have three green leaf branches with white spots with a maximum height of $100 \mathrm{~cm}$, while the adults have a height of $180 \mathrm{~cm}$ with three main leaf branches and are further divided into 2-3 leaf branches. The fruit is green when it is not ripe and yellow when ripe. The leaves are green, oval in shape, and the tip of the leaf is pointed.

\subsection{Distribution of Amorphophallus at Each Altitude}

Based on the distribution map of Amorphophallus at several altitudes on Mount Poteng, it shows that the distribution of Amorphophallus can be found from an altitude of $200->500$ masl with a distance not far from the river stream (Fig. 6). The distribution map of Amorphophallus found in Mount Poteng shows that A. borneensis is more common than A. gigas. It might be due to A. borneensis is one of the endemic Amorphophallus species of West Kalimantan. Therefore, it has the best adaptability among the three Amorphophallus species. This tendency proved that $A$. borneensis could adapt to forest environmental conditions at different altitudes. Aji et al. (2018) explained that Amorphophallus spp. can grow in all soil conditions except on swampy or brackish soils and grows well in soils that contain high organic matter with a $\mathrm{pH}$ of 6-7.5. Meanwhile, $A$. 
gigas was the least in number because A. gigas was included in the endemic Amorphophallus species of Sumatra, so it had poor adaptability compared to the three Amorphophallus species. Data on the number of Amorphophallus individuals based on altitude on Mount Poteng is shown in Table 1.

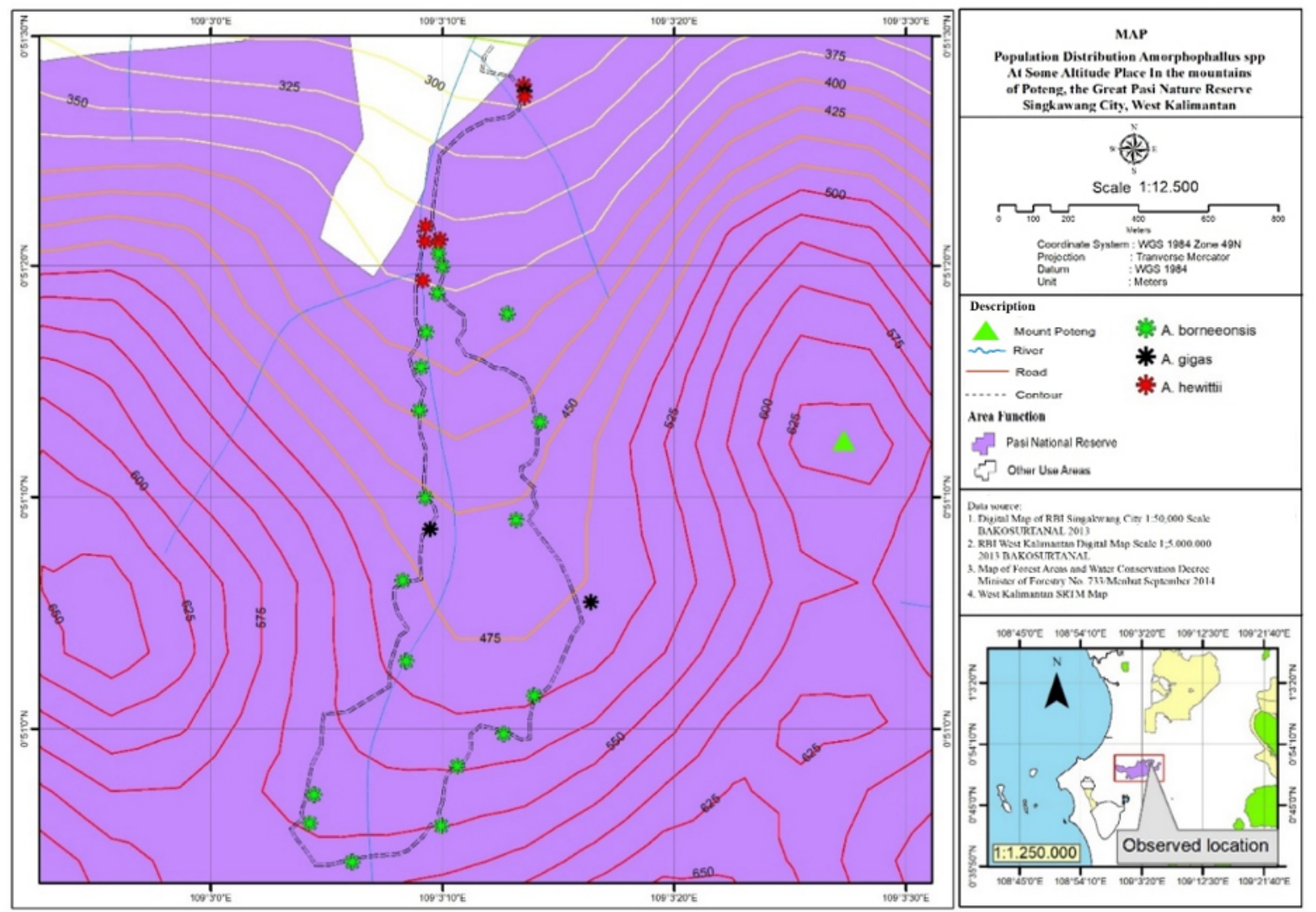

Fig. 6. Amorphophallus distribution at each altitude.

Table 1 shows that Amorphophallus was most commonly found at an altitude of $300-<400$ masl ( 72 individuals) and the least at an altitude of $>500$ masl ( 6 individuals). It might be due to the lack of water sources with the increase in altitude. All Amorphophallus found at an altitude of $300-<400$ masl are not far from the river stream compared to Amorphophallus at an altitude of $>500$ masl, which is far from the river stream and lots of rocks. According to Nursanti et al. (2019), the population of A. titanium was always found not far from water sources because a good hydrological cycle was an essential factor for the growth of Amorphophallus. The $\mathrm{pH}$ of the soil at an altitude of $>500$ masl is classified as acidic $\mathrm{pH}(\mathrm{pH} 5.38)$ and the lowest compared to other altitudes. Therefore, Amorphophallus plants grow well in soils with a $\mathrm{pH}$ of 6.0-7.5 (Supriati 2016). However, according to Aji et al. (2018), Amorphophallus spp. can grow in all soil conditions except swamp or brackish soil and grows well in soils with high organic content.

Table 1. Number of Amorphophallus species based on altitude in Mount Poteng

\begin{tabular}{ccccccc}
\hline \multirow{2}{*}{ Species } & \multicolumn{5}{c}{ Altitude (masl) } & \multirow{2}{*}{ Total } \\
\cline { 2 - 6 } & $\mathbf{2 0 0}-<\mathbf{3 0 0}$ & $\mathbf{3 0 0}-<\mathbf{4 0 0}$ & $\mathbf{4 0 0}-<\mathbf{5 0 0}$ & $\mathbf{5 0 0}$ & \\
\hline Amorphophallus borneensis & - & 57 & 46 & 6 & 109 \\
Amorphophallus gigas & 7 & - & 2 & - & 9 \\
Amorphophallus hewittii & 12 & 15 & - & - & 27 \\
\hline Total & 19 & 72 & 48 & 6 & 145 \\
\hline
\end{tabular}




\subsection{Morista Index}

The Morista index was used to determine the distribution pattern of a species, whether it is classified as random, clustered, or uniform. The value of the Morista index of three Amorphophallus species at several altitudes is presented in Table 2.

Table 2. Morista index $\left(I_{\delta}\right)$ of Amorphophallus species at several altitudes

\begin{tabular}{lccccccc}
\hline \multirow{2}{*}{ Species } & \multicolumn{5}{c}{ Altitude (masl) } & \multirow{2}{*}{ Number } & $\boldsymbol{I}_{\boldsymbol{\delta}}$ \\
\cline { 2 - 6 } & $\mathbf{2 0 0}-\mathbf{-} \mathbf{3 0 0}$ & $\mathbf{3 0 0}-<\mathbf{4 0 0}$ & $\mathbf{4 0 0}-<\mathbf{5 0 0}$ & $\mathbf{> 5 0 0}$ & & 109 & 1.79 \\
A. borneensis & - & 57 & 46 & 6 & 9 & 2.44 \\
A. gigas & 7 & - & 2 & - & 27 & 1.95 \\
A. hewiitti & 12 & 15 & - & - & 145 & \\
\hline \multicolumn{1}{c}{ Total } & 19 & 72 & 48 & 6 & \\
\hline
\end{tabular}

Table 2 shows that the results of the morista index calculation for the three Amorphophallus species found in the research location have a value of more than one $\left(I_{\delta}>1\right)$. Therefore, the distribution pattern was categorized as clustered. Our result was in line with the previous studies (Arianto et al. 2018; Nursanti et al. 2019; Saragih et al. 2015), stating that the distribution of Amorphophallus is clustered. The clustered distribution pattern is common in nature. The condition of clustered distribution illustrated that Amorphophallus has a relatively similar growth place. Group dispersal also occurred because of the earth's gravity and water flow on the forest floor, which carries Amorphophallus flower seeds to the forest floor (Arianto et al. 2018). Porang (Amorphophallus muelleri) grows wild in several areas in the Jember district from a clustered or random distribution pattern because Porang grows naturally (Sari et al. 2013).

\subsection{Similarity Index}

The similarity index value shows the similarity of the Amorphophallus individual number from different altitudes compared. The results showed that the overall altitude comparisons have similar values of similarity index, except one altitude comparison $(200-<300$ and $>500)$ has a very different category value (Table 3). This is because the number of individuals from species that are not found at the altitudes compared and the environmental factors present at each altitude is different, allowing for the spread of species that are not always present at all altitudes but at different altitudes. Fitria et al. (2019) also reported that the differences in the communities were due to the different environmental factors in the two locations being compared. Destaranti et al. (2017) stated that the species similarity index value is affected by the number of individuals of the same species between the two communities being compared.

Table 3. The similarity index values at each altitude

\begin{tabular}{clc}
\hline No & Altitude (masl) & Similarity index (\%) \\
\hline 1 & $200-<300$ and $300-<400$ & 50.00 \\
2 & $200-<300$ and $400-<500$ & 50.00 \\
3 & $200-<300$ and $>500$ & 0.00 \\
4 & $300-<400$ and $400-<500$ & 50.00 \\
5 & $300-<400$ and $>500$ & 66.67 \\
6 & $400-<500$ and $>500$ & 66.67 \\
\hline
\end{tabular}




\subsection{Habitat and Growth Place of Amorphophallus}

The height and the amount of vegetation and the altitude of a place, light intensity, humidity, and air temperature can affect the spread and growth of Amorphophallus itself. Altitude is closely related to environmental factors. The difference in altitude causes variations in the habitat in the form of differences in temperature and humidity. This difference will affect the mosses and cyanobacteria that give the appearance of the pseudo-stem of Amorphophallus. Thus, in this study, the same species, namely A. gigas, was found at different altitudes, showing slightly different stem patterns (Fig. 7). The mimicry of mosses and cyanobacteria causes the stem pattern in Amorphophallus. Claudel et al. (2019) explained that in moist habitats, cyanobacteria and mosses are commonly found to grow together on tree trunks. Their coloration and pattern on leaf stalks with a visual resemblance to tree trunks surrounded by similar cyanobacteria and leaf stalk appearance are often bluish-green or brownish-red. These morphological differences can also occur in different species.
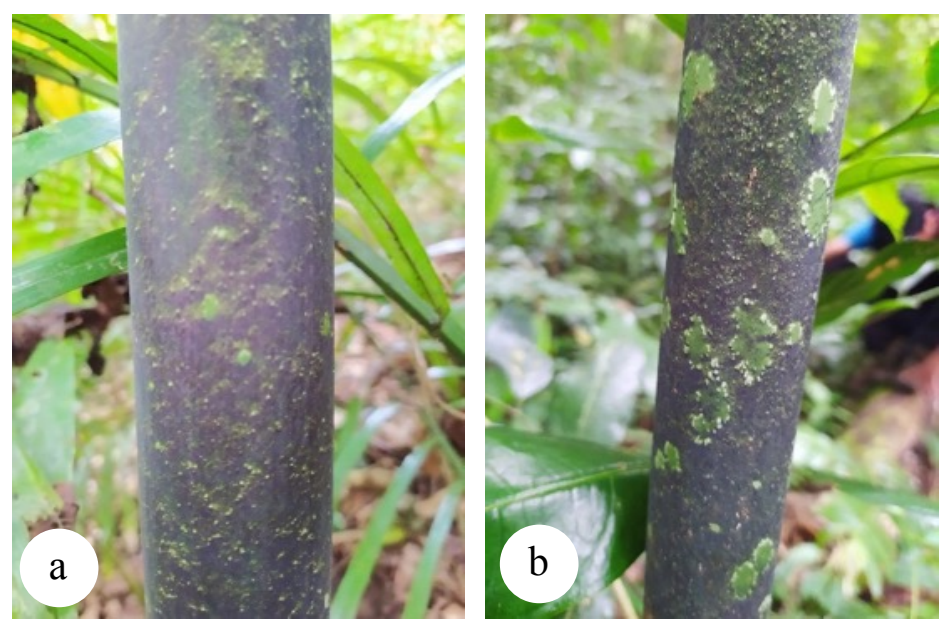

Fig. 7. Stem pattern of A. gigas: (a) $200-<300$ masl, and (b) $400-<500$ masl.

The growth places of Amorphophallus in the research location were on the forest floor, forest edges, river flows, and rocky areas. However, it was found more dominant around the river. Hidayat (2019) said that the population of $A$. paeoniifolius is mostly clustered along forest edges, vacant land, riverbanks, or conservation forest edges. So naturally, Amorphophallus sp. was spread in the Sumatran rain forest as understorey canopies on calcareous soils. However, Amorphophallus sp. was also found in open areas of secondary forests, roadsides, riverbanks, or forest edges (Latifah and Purwantoro 2015).

\subsection{Environmental Factors of Amorphophallus Growth Place}

A natural succession process naturally causes the number of Amorphophallus. The environmental conditions of its growth place also affect the population distribution in Mount Poteng. The measurements at the research location show that the environmental factor that increases with every increase in altitude is air humidity, while air temperature decreases with every increase in altitude (Table 4).

Table 4 shows that air temperatures tended to decrease with the increase of altitude, showing an average air temperature ranging from $24.43-25.90^{\circ} \mathrm{C}$. This is because the condition of the area is slightly covered by vegetation, and the weather conditions were cloudy at the time of the study, 
so only less sunlight entered the forest floor. Another study also said that $A$. titanum sites in Muara Hemat Village have an average temperature of $24-25^{\circ} \mathrm{C}$ (Nursanti et al. 2019), while A. hewittii sites have an average temperature of $24.20-27.20^{\circ} \mathrm{C}$ (Saragih et al. 2015). The relative humidity showed a different tendency, showing an increase of relative humidity with the increase of altitude. This is because the area is covered by vegetation, resulting in less light intensity entering the forest floor. The relative humidity in this area is between $86.57-90.10 \%$ (Table 4). In contrast, Nursanti et al. (2019) stated that the relative humidity of $A$. titanium is between $80-83 \%$.

Table 4. The results of the average measurement of environmental factors at several altitudes

\begin{tabular}{lcccr}
\hline \multirow{2}{*}{ Environmental Factors } & \multicolumn{4}{c}{ Altitude (masl) } \\
\cline { 2 - 5 } & $\mathbf{2 0 0}-<\mathbf{3 0 0}$ & $\mathbf{3 0 0}-<\mathbf{4 0 0}$ & $\mathbf{4 0 0}-<\mathbf{5 0 0}$ & \multicolumn{1}{c}{$\mathbf{5 0 0}$} \\
\hline Light intensity (lux) & 181.00 & 318.08 & 301.56 & 144.00 \\
Air temperature $\left({ }^{\circ} \mathrm{C}\right)$ & 25.90 & 25.61 & 24.82 & 24.43 \\
Relative humidity $(\%)$ & 86.57 & 88.28 & 89.71 & 90.10 \\
Soil solum $(\mathrm{cm})$ & 6.33 & 6.31 & 6.00 & 6.75 \\
Soil pH & 6.03 & 5.42 & 5.48 & 5.38 \\
Soil temperature $\left({ }^{\circ} \mathrm{C}\right)$ & 25.67 & 24.77 & 24.67 & 25.00 \\
\hline
\end{tabular}

\subsection{Relationship of Environmental Factors and Amorphophallus Distribution}

The relationship between environmental factors and Amorphophallus determines the direction of the close relationship between two variables, whether positive or negative. Table 5 shows the highest correlation value obtained from each environmental factor that affects Amorphophallus distribution. The overall results of correlation analysis of the three Amorphophallus species showed that the correlations are within a weak category.

Table 5. The correlation analysis results on the number of Amorphophallus distribution

\begin{tabular}{lcc}
\hline Species & R-squared & Regression equation \\
\hline A. borneensis & 0.035 & $Y=-24.43+1.12 X$ \\
A. gigas & 0.358 & $Y=-27.87+1.13 X$ \\
A. hewittii & 0.414 & $Y=62.38-0.69 X$ \\
\hline
\end{tabular}

The relationship between air temperature and $A$. borneensis distribution shows an R-squared value of 0.035 . It can be interpreted from the regression equation $(Y=-24.43+1.12 X)$ that for every $1 \%$ addition of air temperature, the number of $A$. borneensis will increase by $1.12(1 \%)$. The regression coefficient is positive, so it can be said that the direction of the influence of the variable $X$ on $Y$ is positive. The average air temperature ranges from $24.43-25.9^{\circ} \mathrm{C}$, which decreases with every increase in altitude. Saragih et al. (2015) reported that $A$. hewittii was found at $24.2-27.2^{\circ} \mathrm{C}$. Because air temperature does not dominate the distribution of $A$. borneensis, the interaction with abiotic factors such as river flow might affect $A$. borneensis distribution as the plants are mostly found not far from the river stream compared to those far from the river stream. Another study reported that the population of A. titanum was mainly found not far from water sources because a good hydrological cycle is an essential factor for the growth of Amorphophallus (Nursanti et al. 2019). 
The relationship between soil temperature and A. gigas distribution shows an R-squared value of 0.035 , meaning that $36 \%$ of the distribution was influenced by soil temperature; the rest were other factors. The regression equation $(Y=-27.87+1.13 X)$ states that for every $1 \%$ increase in soil temperature, the amount of $A$. gigas will increase by $1.13(1 \%)$. The regression coefficient is positive, so it can be said that the direction of the influence of the variable $\mathrm{X}$ on $\mathrm{Y}$ is positive. The mean soil temperatures at an altitude of $200-<300$ masl and $400-<500$ masl where A. gigas was found were $25.67^{\circ} \mathrm{C}$ and $24.67^{\circ} \mathrm{C}$, respectively (Table 4). In contrast to the soil temperature, the soil $\mathrm{pH}$ decreased with each increase in altitude, while soil solum showed inconsistent tendency with the increase of altitude. Supriati (2016) stated that Amorphophallus grows well in soils with a $\mathrm{pH}$ of 6.0-7.5. In addition, Aji et al. (2018) stated the optimal soil temperature for Amorphophallus spp. ranges from $22-30^{\circ} \mathrm{C}$.

The relationship between relative humidity and $A$. hewittii distribution shows an R-squared value of 0.414 , meaning that $40 \%$ of the total distribution was influenced by relative humidity and other factors. The regression analysis results with the equation $Y=62.38-0.69 X$ stated that every $1 \%$ increase in relative humidity would reduce $1 \%$ the number of $A$. hewittii. The regression coefficient is negative because $A$. hewittii can grow well in low humidity. The altitude of a location is closely related to light intensity, air temperature, and humidity. Mulyati et al. (2017) stated that physical factors such as temperature, soil $\mathrm{pH}$, humidity, and light intensity strongly influenced the survival of Amorphophallus. Saragih et al. (2015) stated that the growth and distribution of $A$. hewittii were influenced by a combination of tree-level and pole-level vegetation and the altitudes of the location.

\section{Conclusions}

The differences in morphological characteristics of the three Amorphophallus species found in Mount Poteng were in the forms of the stem pattern, stem height, and fruit shape. Based on the altitude on Mount Poteng, the distribution of Amorphophallus can be found at an altitude of $200-$ $<500$ masl, which is mainly not far from the river stream. The distribution pattern is all clustered. The species similarity index of six comparisons for each altitude showed five altitudes with similar categories and one altitude with a very different category. This study also revealed that Amorphophallus distribution positively correlated with air temperature and soil temperature but negatively correlated with air humidity.

\section{References}

Aji, L. M. I., Wahyuningsih, E., and Patoni, P. 2018. Identifikasi Hasil Hutan Bukan Kayu Genus Amorphophallus di Desa Satong Kecamatan Kayangan Kabupaten Lombok Utara. Jurnal Belantara 1(2): 107-114. DOI: 10.29303/jbl.v1i2.71

Arianto, W., Zuhud, A. M. E., Hikmat, A., Sunarmito, T., and Siregar, I. Z. 2018. Populasi dan Struktur Kompoisi Vegetasi Habitat Bunga Bangkai (Amorphophallus titanum [Becc] Becc.EL Arcang) di Kawasan Hutan Bengkulu. Journal of Natural Resources and Environmental Management 9(2): 241-257. DOI: 10.29244/jps1.9.2.241-257

Aisah, N. B., Soegianto, A., and Basuki, N. 2017. Identifikasi Morfologi Dan Hubungan Kekerabatan Tanaman Porang (Amorphophallus muellery Blume) di Kabupaten Nganjuk, Madiun dan Bojonegoro. Jurnal Produksi Tanaman 5(6): 1035-1043. 
Claudel, C., Yadun-Lev, S., Hetterscheid, and Schultz, M. 2019. Mimicry of Lichens and Cyanobacterial on Tree-Sized Amorphophallus Petioles Results in Their Masquerade as Inedible Tree Trunks. Botanical Journal of Linnean Society of London 190: 192-214. DOI: 10.1093/botlinnean/boz014

Destaranti, N., Sulistiyani, and Edy, Y. 2017. Struktur dan Vegetasi Tumbuhan Bawah pada Tegakan Pinus di RPH Kalirajut dan RPH Baturraden Banyumas. Scripta Biologica 4(3): 155-160. DOI: 10.20884/1.sb.2017.4.3.407

Fitria, F., Widodo, P., and Widyastuti, A. 2019. Keanekaragaman Tumbuhan Bunga Liar di Cagar Alam Batarbolang Pamalang Jawah Tengah. Jurnal Ilmiah Biologi Unsoed 1(2): 8-16.

Heriyansyah, F., Soetopo, L., and Sapradi, D. 2017. Eksporasi dan Identifikasi Karakter Morfologi Anaman Suweg (Amorphophallus campanulatus BI) di Jawa Barat. Jurnal Produksi Tanaman 5(3): 377-382.

Hidayat, S. 2019. The Study of Suweg (Amorphophallus paeoniifolius) and Other Undergrowth Species in Teak Plantation Forest of Temengeng, Blora, Indonesia. Biodiversitas 20(1): $37-$ 42. DOI: $10.13057 /$ biodiv/d200105

Jintan, Yuzammi, Suwastika, I. N., and Pitopang, R. 2015. Studi Beberapa Aspek Botani Amorphophallus paeoniifolius Dennst. Nicolsom (Araceae) di Lembah Palu. Journal of Natural Science 4(1):17-31. DOI: 10.22487/25411969.2015.v4.i1.4008

Khairil, M., Dewantara, I., and Widiastuti, T. 2015. Studi Keanekaragaman Kantong Semar (Nepenthes spp.) di Kawasan Hutan Bukit Beluan Kecamatan Hulu Gurung. Jurnal Hutan Lestari 3(2): 259-264. DOI: 10.26418/jhl.v3i2.10389

Kementerian Lingkungan Hidup dan Kehutanan (KLHK). 2020. Vandemecum Kehutanan Indonesia 2020. KLHK. Jakarta.

Latifah, D., and Purwantoro, R. S. 2015. Seed Germination of the Corpse Giant Flower Amorphophallus titanum (Becc.) Becc. Ex Arcang: The Influence of Testa. Berita Biologi 14(1): 39-48. DOI: 10.14203/beritabiologi.v14i1.1861

Mulyati, M., Djufri, D., and Supriatno, S. 2017. Analisis Vegetasi Naungan Bunga Bangkai (Amorphophallus peoniifolius (Dennts.) Nicholson) di kawasan Padang Tiji Kabupaten Pidie. Jurnal Ilmiah Mahasiswa Keguruan dan Ilmu Pendidikan Unsyiah. 2(1): 98-106.

Nursanti, N., Wulan, C., and Felicia, M. R. 2019. Bioekologi Bunga Bangkai (Amorphophallus titanum (Becc.) Becc.) di Desa Muara Hemat Resort Kerinci Selatan Taman Nasional Kerinci Seblat. Jurnal Silva Tropika 3(2): 162-174.

Saragih, S. E., Astiani, D., and Sisillia, L. 2015. Sebaran Populasi dan Kondisi Tempat Tumbuh Bunga Bangkai (Amorphophallus sp.) di Kawasan Hutan Kota Gunung Sari Kota Singkawang. Jurnal Hutan Lestari 4(3): 282-291. DOI: 10.26418/jhl.v4i3.15816

Sari, R. W., Azrianingsih, R., and Rahardi, B. 2013. Peta dan Pola Persebaran Porang (Amorphophallus Muelleri Blume) pada Beberapa Area di Kabupaten Jember. Biotropika 1(4): 144-148.

Supriati, Y. 2016. Keanekaragaman Iles-Iles (Amorphophallus spp.) dan Potensinya untuk Industri Pangan Fungsional, Kosmetik, dan Bioetanol. Jurnal Litbang Pertanian 35(2): 69-80. DOI: 10.21082/jp3.v35n2.2016.p69-80

Tarida, T., Pribadi, R., and Pramesti, R. 2018. Struktur dan Komposisi Gastropoda pada Ekosistem Mangrove di Kecamatan Genuk Kota Semarang. Jurnal of Marine Research 7(2): 106-112. DOI: $10.14710 /$ jmr.v7i2.25899 
Yuzammi, Witono, J. R., and Hetterscheid, W. L. A. 2014. Conservation Status of Amorphophallus discophorus Backer \& Alderw. (Araceae) in Jawa, Indonesia. Reinwardtia 14(1): 27-33. DOI: 10.14203/reinwardtia.v14i1.392

Yuzammi, Mursidawati, S., Asikin, D., Sugiarti, Gunawan, H., Nugroho, A., and Rahmat, U. M. 2015. Strategi dan Rencana Aksi Konservasi Bunga Bangkai (Amorphophallus titanum) 2015-2025. Direktorat Jenderal Konservasi Sumber Daya Alam dan Ekosistem Kementerian Lingkungan Hidup dan Kehutanan Republik Indonesia. Jakarta. 